ERC Working Papers in Economics 17/09

September / 2017

\title{
Long Memory in Turkish Unemployment Rates
}

\author{
Luis A. Gil-Alana \\ Faculty of Economics and ICS, University of Navarra, Pamplona, Spain \\ E-mail: alana@unav.es \\ Phone: + (34) 948425625
}

\section{Zeynel Abidin Ozdemir}

Department of Economics, Gazi University, Ankara, Turkey and

Economic Research Forum (ERF), Cairo, Egypt

E-mail: zabidin@gazi.edu.tr

\section{Aysit Tansel}

Department of Economics, Middle East Technical University, Ankara, Turkey and Institute for the Study of Labor (IZA), Bonn, Germany and Economic Research Forum (ERF), Cairo, Egypt

E-mail: atansel@metu.edu.tr

Phone: + (90) 3122102073 


\title{
Long Memory in Turkish Unemployment Rates
}

\author{
Luis A. Gil-Alana \\ University of Navarra, Faculty of Economics and ICS, Pamplona, Spain \\ Zeynel Abidin Ozdemir \\ Gazi University, Department of Economics, Besevler, 06500, Ankara, Turkey \\ Economic Research Forum (ERF) Cairo, Egypt \\ Aysit Tansel \\ Middle East Technical University, 06800 Ankara, Turkey \\ Institute for the Study of Labor (IZA), Bonn, German \\ Economic Research Forum (ERF), Cairo, Egypt
}

May 42017

\begin{abstract}
In this paper we have examined the unemployment rate series in Turkey by using long memory models and in particular employing fractionally integrated techniques. Our results suggest that unemployment in Turkey is highly persistent, with orders of integration equal to or higher than 1 in most cases. This implies lack of mean reversion and permanence of the shocks. We found evidence in favor of mean reversion in the case of female unemployment and this happens for all the groups of non-agricultural, rural, urban and youth unemployment series. The possibility of non-linearities are observed only in the case of female unemployment and the degree of persistence is higher in the cases of female and youth unemployment series. Important policy implications emerge from our empirical results. Labor and macroeconomic policies will most likely have long lasting effects on the unemployment rates.
\end{abstract}

Keywords: Unemployment, hysteresis, NAIRU, fractional integration, Turkey JEL Classification: C22, E24

Corresponding author:

Luis A. Gil-Alana

University of Navarra

Faculty of Economics

Edificio Amigos, E-31080 Pamplona

SPAIN

Phone:+34 948425625

Fax: +34948425626

Email: alana@unav.es

\footnotetext{
*: Prof. Luis A. Gil-Alana gratefully acknowledges financial support from the Ministerio de Economia y Competitividad (ECO2014-55236).
} 


\section{Introduction}

Analyzing the dynamic statistical characteristics of unemployment rates has gained in popularity in recent years in the applied macroeconomics literature. Within this literature four main theories have been formulated in order to explain unemployment behavior. First, the NAIRU (Non-Accelerating Inflation Rate of Unemployment) establishes that shocks only have transitory effects and there exists a long run unemployment rate. Second, the structuralist viewpoint, states that changes in fundamentals may shift the equilibrium unemployment rate over time, which is a more relaxed version of the NAIRU theory. Given the high unemployment rate seen in European countries in recent decades, two more theories have arisen; the persistence hypothesis explains unemployment as a variable that needs long periods to recover after a shock, whereas the hysteresis hypothesis implies that unemployment can be characterized as a random walk, or more generally, a unit root or I(1) process, which never reverts to an equilibrium after a shock. If unemployment is characterized as a unit root process (hysteresis), macroeconomic policy measures should focus on structural reforms in order to counter a negative shock. On the contrary, if unemployment turns out to be a stationary $\mathrm{I}(0)$ process (NAIRU), macroeconomic policy should focus on the prevention of short run departures from the equilibrium.

The dynamic properties of unemployment rates have been widely discussed for industrialized countries, with particular attention given to Western Europe and the US. The reason is, at least, twofold. First, high unemployment rates have not only economic, but also political and social consequences (Layard et al., 2005). Second, despite the fact that European unemployment rates traditionally have been high and persistent, the recent 
2008-2009 economic crisis has pushed unemployment rates even higher. This situation casts doubts about the empirical fulfilment of the natural rate of unemployment (NAIRU).

The unemployment rate in Turkey is rather high compared to that of the OECD countries: $10.3 \%$ versus an average of $6.8 \%$ in 2015 . There are a number of recent papers that investigate the stationarity properties of the Turkish unemployment rates albeit with conflicting conclusions. The results of this paper will hopefully end this bifurcation.

The standard unit root tests consider only integer numbers for the order of integration of a series. This restriction may not be realistic. In this paper we use a version of the tests of Robinson (1994) which considers the possibility of any real value for the order of integration on the unit interval or above unity. This is referred to as fractional integration or I(d) behavior. In addition, we use a non-linear approach (Cuestas and GilAlana, 2016) that remains valid in fractionally integrated contexts. We apply this approach to the unemployment series of Turkey by gender and by various subgroups such as non-agricultural, urban, rural, and youth. The results indicate that the unemployment series are highly persistent with values above 0.5 in all cases and thus showing nonstationary behavior. Although the unit root null hypothesis cannot be rejected in the majority of the cases, some evidence of mean reversion is obtained for female series in the groups of non-agricultural rural and urban unemployment rate series as well as for the youth series, with higher degree of persistence for these two groups. Our empirical results have important policy implications such as the long lasting effects of active labor market polices. 
The rest of the paper is organized as follows. The next section briefly sets out the different economic theories about the dynamics of unemployment. Section 3 summarizes recent contributions dealing with the order of integration of unemployment rates series using time series techniques in several countries as well as Turkey. In Section 4 we present the methodology employed in the paper. Section 5 describes the data. Section 6 summarizes the main results from applying unit roots and fractional integration techniques in the Turkish unemployment rate series; finally, the last section concludes the paper.

\section{Unemployment hypothesis}

From a theoretical perspective the first hypothesis regarding the dynamic behavior of unemployment is the NAIRU hypothesis, according to which there is a unique long run equilibrium for unemployment rates. Therefore, the Phillips Curve is vertical meaning that there is no trade-off between inflation and output in the long run. In the short run however there may be transitory deviations from the long run equilibrium, implying that the variable is a stationary and mean reverting process where shocks only have transitory effects. Hence, the NAIRU hypothesis might be consistent with values of $\mathrm{d}$ belonging to the interval $[0,0.5)$, with shocks disappearing fairly quickly.

The reality of recent decades has provoked doubts on the empirical validity of the NAIRU hypothesis, at least for European countries. A less restrictive version of the NAIRU theory is the one followed by structuralists, who believe that changes in the underlying fundamentals may affect the NAIRU permanently, i.e. result in structural changes and a shift from one equilibrium to another. Phelps (1972), in his book, proposes 
some theoretical models to explain changes in the natural rate of unemployment, which are due to changes in economic fundamentals, i.e. interest rates, expenditure, capital, productivity, etc. These models use not only macro, but also micro foundations to explain shifts in unemployment rates (see also Layard et al., 2005, for a summary of these models). The structuralist theory implies that unemployment rates should be an $\mathrm{I}(0)$ process (or $\mathrm{I}(\mathrm{d})$ with $\mathrm{d}<0.5)$ around a changing or time varying equilibrium value (Papell et al. 2000). Under this theory, the empirical analysis should be done by means of unit root or I(d) tests that account for the possibility of structural changes. ${ }^{1}$ Otherwise, traditional unit root tests may fail to reject the null hypothesis in the presence of structural breaks in the deterministic components.

Current unemployment rates, by appearing to indicate nonstationary, or even explosive, processes, suggest the NAIRU hypothesis may not be a correct theoretical starting point. In contrast, the hysteresis hypothesis (Blanchard and Summers, 1986, 1987 and Barro, 1988) appears to offer more promising avenues for investigation. According to this hypothesis, shocks to unemployment will never die out, and the variable will never come back to its equilibrium value, which is a characteristic of unit root or explosive processes. A number of factors explain this behavior. They include presence of powerful unions, disproportionately high real wages, employment protection schemes, and the social stigma of the long term unemployed and these are discussed by a number of authors (Phelps, 1972; Blanchard and Summers, 1986, 1987; Clark, 2003, Layard et al., 2005, and Cuentas and Ordóñez, 2011 amongst others). Also, Cross (1995) explains that hysteresis is a non-linear phenomenon, explained mainly by the existence of heterogeneous agents. That said, unemployment could eventually revert to equilibrium

\footnotetext{
1 Note that fractional integration and structural breaks are issues which are very much related. See, for instance, Sibbertsen (2004), Gil-Alana (2008), Baillie and Morana (2009).
} 
after a long period of time. This is a feature of nonstationary long memory processes, $\mathrm{d} \in$ $[0.5,1)$ (see Table 1) when the series is mean reverting though with the effect of the shocks taking a very long time to disappear completely.

\section{[Insert Table 1 about here]}

In this paper we confront this theoretical ambiguity over the most appropriate theoretical explanation for unemployment dynamics of Turkey, by means of unit roots and fractional integration tests. These tests, which will be explained in detail in Section 4, can provide empirical support for one or other theory of unemployment dynamics, by focusing on their underlying statistical properties.

\section{Brief literature review}

Testing for unit roots in unemployment rates has traditionally been an appealing way to test for the empirical fulfilment of unemployment theories. Early studies applied the Augmented Dickey-Fuller (Dickey and Fuller, ADF, 1979) and Phillips-Perron (Phillips and Perron, PP, 1988) unit root tests in order to analyze whether the order of integration of unemployment rates was 0 or 1 . Thus, Blanchard and Summers (1986), Mitchell (1993), Brunello (1990), Nelson and Plosser (1982) and Roed (1996), find in general that European unemployment contains a unit root, whereas the results for the US are more ambiguous.

The above mentioned unit root tests may however present power problems when there are structural breaks in the data generation process. In this case, these tests may 
incorrectly conclude that unemployment is integrated of order I(1), when in fact it is stationary around a broken or shifting drift (see Perron, 1989). Examples of papers that applied unit root tests with structural breaks to unemployment rate series are Mitchell (1993), Bianchi and Zoega (1998), Arestis and Mariscal (1999), Papell et al. (2000), Ewing and Wunnava (2001), and Chien-Chiang and Chun-Ping (2008) who, in general, found evidence in favor of the structuralist view of unemployment dynamics. Another series of papers analyze the order of integration of unemployment rates by means of unit root tests for panel data, in order to take into account cross-sectional information. Thus, Song and $\mathrm{Wu}(1997,1998)$ and León-Ledesma (2002) find that the hysteresis hypothesis is supported by EU data, whereas the NAIRU theory is more appropriate to characterize US unemployment. On the other hand, Christopoulos and León-Ledesma (2007) find evidence against the hysteresis hypothesis for EU data. The issue of structural breaks is considered by other authors who apply panel unit root tests with structural breaks (Murray and Papell, 2000, and Strazicich et al. 2001), finding more evidence supporting the structuralist theory of unemployment.

Unemployment shocks may die out after a long period of time, which may also increase the likelihood of Type II errors through the unit root and stationarity tests used in these studies. In this situation unit root tests may fail to reject the null hypothesis when the processes are fractionally integrated with a differencing parameter close to but less than 1 . In this case, although the variable is not a stationary process, it still presents mean reversion. ${ }^{2}$ Fractional integration analysis thus provides us with greater analytical flexibility: by estimating the value of $\mathrm{d}$, we can make an assessment about the validity of

\footnotetext{
${ }^{2}$ Some authors argue that the concept of mean reversion in nonstationary series is a misnomer (Phillips and Xiao, 1999). However, the idea behind this is that under mean reversion the series should converge to its original long term projection.
} 
alternative theories of unemployment (as summarized in Table 1). Thus, recent contributions Gil-Alana (2001a,b, 2002) and Caporale and Gil-Alana (2007, 2008), among others, conclude through applying ARFIMA models, that the structuralist view is more appropriate as a characterization of European unemployment, while the NAIRU explains better the behavior of the US data. Finally, the existence of non-linearities is also accounted for, given that the unemployment rate's speed of adjustment towards equilibrium may be dependent on the degree of misalignment. This implies that there may exist a threshold of values for the unemployment rate where the variable behaves as a unit root (inner regime), but when the variable departs from the inner regime, it behaves as a mean reverting process. In policy terms, this implies that the authorities should not implement policy measures for small deviations of unemployment from the equilibrium, given that the costs will offset the benefits. However, when unemployment reaches higher values, policy intervention to affect the underlying fundamentals may reduce actual unemployment rates. Examples of empirical papers that deal with non-linearities in unemployment rates are Bianchi and Zoega (1998), Skalin and Teräsvirta (2002) and Caporale and Gil-Alana $(2007,2008)$.

\subsection{The case of Turkey}

The literature on the investigation of the time series properties of the unemployment rate in Turkey is vast and offers conflicting conclusions. There are studies that consider different time periods with data of various frequencies employing different methodologies. We first review those studies that use annual data going back to 1923 . Barişik and Çevik (2008) and Pazarlığlu and Çevik (2007) use annual data for 19232006 and using ARFIMA models find evidence for hysteresis. Similarly, Y1lanc1 (2009) 
consider the period 1923-2007 and Yıldırım (2011) and Koçyiğit, Bayat and Tufekçi (2011) the 1923-2010 period. The two former studies take structural breaks into account and the latter study considers STAR models. All three studies conclude that the unemployment rate series is nonstationary. Bayat, Kayhan and Koçyiğit (2013) used the data for the 1923-2011 period and examined the asymmetric behavior in the unemployment rate with a Markov regime change model, concluding in favor of nonstationarity. Küçükkale (2001) used data from 1950 to 1995 and using the Kalman filter method, they find support for the hysteresis hypothesis.

Next we review those studies that still use annual data but for a shorter period of time. Güloğlu and İspir (2011) used 1998-2008 data for nine sectors. When they take structural breaks into account they accept the natural rate hypothesis. Özcan (2012) uses unit root tests with structural breaks and finds that for most of the OECD countries including Turkey, the hysteresis hypothesis of unemployment is validated. Tokatlioğlu, Öztürk and Ardor (2014) analyzed 15 European Union (EU) countries, including Turkey, over 1988-2011. They find low hysteresis effects for the total male and female series investigated separately. Khraief, Shahbaz, Heshmati and Azam (2015) consider 29 OECD countries which include Turkey over the period 1980-2013. They also carry out ESTAR non-linear unit root tests. They find non-linearity in the Turkish case but conclude that the unemployment rate in Turkey is stationary. Moghaddasi and Raini (2015) study Iran, Pakistan and Turkey over the period 1975-2010. They find two endogenously determined structural breaks for Turkey in 1986 and 2006. They find support for hysteresis hypothesis. Cinar, Akay and Yilmaz (2014) consider the period 1988-2008 and use methods without and with multiple structural breaks. In addition to the total unemployment rate they also analyze the unemployment rate in the three main economic 
sectors, agriculture, industry and services. In all cases they reject the hysteresis hypothesis.

There are several studies that consider groups of countries and apply panel unit root tests. Ener and Arica (2011 a,b) is one example of such studies. They consider 15 OECD countries including Turkey with annual data for the period 1985-2008. Allowing for cross sectional dependency between the series they find that the series are stationary with structural breaks. Similarly, this holds for Turkey, implying a unique natural rate of unemployment. In a similar vein Gözgör (2012) considers the regions of Turkey. Gözgör (2012, 2013) uses annual data for the period 2004-2011 for the 26 regions of Turkey. He uses eight different panel unit root tests with and without structural breaks and cross sectional dependence, concluding support for the hysteresis hypothesis for 24 of the 26 regions.

Finally, we consider the evidence from studies that used quarterly data. Pazarlığlu and Çevik (2007) used data covering 1988Q1-2004Q1. They found ratchet effect with support for hysteresis hypothesis. Tunalı (2010) used data for the period 2002Q1-2008Q4 and used cointegration analysis, also supporting hysteresis. Yiğit and Gökçe (2012) used structural two variable VAR method in quarterly data for 1988-2011, and estimated the NAIRU for various sub-periods. Akdogan (2015) considered 31 European countries, USA, Japan and Turkey. For Turkey the analysis covers the period 2005Q1-2015Q1. He uses two different STAR models and conducts multiple structural break tests and linear and non-linear unit root tests. The results for Turkey reject the null hypothesis of unit roots. Bayrakdar (2015) used quarterly unemployment rate series for Turkey covering the period 2000Q1-2013Q4. Employing several versions of unit root 
tests with structural breaks, the results confirmed the hypothesis of hysteresis. Finally, Akcay (2013) used monthly data for the period 2005M1-2013M5 for Turkey. Her results indicate that the non-linear unit root tests provide evidence for the natural rate hypothesis. Y1lancı (2008) used monthly data to test the joint null hypothesis of linearity and a unit root. He found that for some OECD countries the hypothesis of the linear unit root is rejected and for some other countries, including Turkey, hysteresis is supported. In contrast to all these time series analysis, Bildirici et al. (2012) used individual level data from Household Labor Force Survey (HLFS) covering the 1980-2010 period and provided evidence for hysteresis in the Turkish unemployment rates.

\section{Methodology}

Many macroeconomic series are nonstationary. Until the 1980s the most common approach to remove it was to impose a deterministic (usually linear) function of time, assuming that the residuals from the regression were stationary $\mathrm{I}(0)$. Later on, and especially after the influential work of Nelson and Plosser (1982), there was agreement that the nonstationary component of the series was stochastic rather than deterministic, and first differentiation (or unit roots or I(1) behavior) was commonly adopted. However, the number of differences required to get $\mathrm{I}(0)$ may not necessarily be an integer value (usually 1) but any point in the real line. In such a case, the process is said to be fractionally integrated or $\mathrm{I}(\mathrm{d}) .^{3}$

\footnotetext{
${ }^{3} \mathrm{The} \mathrm{I}(\mathrm{d})$ processes belong to a wider class of process long memory, so-named because of the strong degree of association between observation which are far distant apart in time.
} 
In this paper we employ a version of the tests of Robinson (1994), which is very general in the sense that it allows us to test any real value of d, including thus cases such as anti-persistence $(d<0)$, short memory $(d=0)$, stationary long memory $(0<d<0.5)$, nonstationary mean reversion $(0.5 \leq d<1)$, unit roots $(d=1)$ or explosive $(d>1)$ behavior, without need of differentiation if the series are nonstationary as is the case with most standard unit root or fractionally integrated methods. It is a Lagrange Multiplier (LM) procedure that uses the Whittle function in the frequency domain. It tests the null hypothesis:

$$
\mathrm{H}_{\mathrm{O}}: \mathrm{d}=\mathrm{d}_{\mathrm{o}} \text {, }
$$

for any real value $\mathrm{d}_{\mathrm{o}}$, in a model given by:

$$
y_{t}=\beta^{T} z_{t}+x_{t}, \quad(1-L)^{d} x_{t}=u_{t}, \quad t=1,2, \ldots .
$$

where $\mathrm{y}_{\mathrm{t}}$ is the observed time series, $\beta$ is a $(\mathrm{kx} 1)$ vector of unknown coefficients and $\mathrm{z}_{\mathrm{t}}$ is a set of deterministic terms that might include an intercept (i.e., $\mathrm{Z}_{\mathrm{t}}=1$ ), an intercept with a linear time trend $\left(\mathrm{z}_{\mathrm{t}}=(1, \mathrm{t})^{\mathrm{T}}\right)$, or any other type of deterministic processes. Robinson (1994) showed that, under certain very mild regularity conditions, the LM-based statistic $(\hat{\mathbf{r}})$ :

$$
\hat{\mathrm{r}} \rightarrow{ }_{\mathrm{d}} \mathrm{N}(0,1) \quad \text { as } \quad \mathrm{T} \rightarrow \infty,
$$

where " $\rightarrow_{\mathrm{d}}$ " stands for convergence in distribution, and this limit behavior holds independently of the regressors $z_{t}$ used in (2) and the specific model for the $I(0)$ disturbances $u_{t}$ in $(2){ }^{4}$

As in other standard large-sample testing situations, Wald and LR test statistics against fractional alternatives have the same null and asymptotic theory as the LM test of

\footnotetext{
${ }^{4}$ For more details, see Gil-Alana and Robinson (1997).
} 
Robinson (1994). In fact, Lobato and Velasco (2007) employed a Wald testing procedure, but this method requires a consistent estimate of d; therefore the LM test of Robinson (1994) seems at least computationally more appealing. The above presented method is purely parametric and therefore we need to specify the functional form of the error term $u_{t}$ in (2). In the empirical application carried out in Section 6 we use two approaches, one based on uncorrelated (white noise) errors, while the other is autocorrelated. However, instead of using standard ARMA methods to describe the autocorrelation, we employ here a non-parametric approach of Bloomfield's (1973) where the model for $\mathrm{u}_{\mathrm{t}}$ is simply specified in terms of its spectral density function. This method approximates fairly well highly parameterized ARMA models with a few number of parameters. In addition, we also use some other semiparametric Whittle approaches (Robinson, 1995; Abadir et al., 2007) where no functional form is imposed on the error term.

\section{The data}

We use seasonally adjusted quarterly data ranging from 1988Q3 until 2013Q4 of Turkish unemployment rates adding up to over 100 observations. In total twelve series were analyzed, namely, Turkey total, non-agricultural, urban and rural unemployment rates for males, females and the entire population. The basic data we use comes from the web pages of the Turkish Statistical Institute (TURKSTAT). The official unemployment rates reported at this source are estimates based on the HLFS. TURKSTAT conducted these surveys for the first time in October 1988, which is why the starting date of our data is 1988Q3. These surveys were done twice a year in April and October during 1989-1999. Starting in 2000 the surveys were implemented four times a year and starting in 2005 the implementation was monthly based on three-month moving average results. Starting in 
2014 there was a change in the questionnaire about the definition of the duration of job search along with other changes which rendered the unemployment rate series before and after 2014 not comparable. This is why the end date of our data is 2013Q4. TURKSTAT reports the quarterly unemployment rates since 2000 . The biannual unemployment rates for the period 1989-1999 are converted to quarterly rates by using the interpolation method of Chow-Lin (1971) based on the GDP series. The GDP series use the production of the national income accounting interpolation. All of the series are checked for seasonality and they are seasonally adjusted using the TRAMO/SEATS procedure due to Gomez and Maravall (1996). As a result of these considerations, we believe we have a consistent quarterly unemployment rate series for the period from 1988Q3 to 2013Q4 including over 100 observations. The plots of the times series are displayed in Figure 1.

\section{[Insert Figure 1 about here]}

We note that the unemployment rate was $10.3 \%$ in 2015 which is above the OECD average of around $6.8 \%$. The number of those looking for work reached almost over three million. The unemployment rate was at a low point in 2012Q2 and has been rising since. In contrast it has been falling for the OECD. In addition to total unemployment we also consider the gender distinction in our analysis. It is important to differentiate the analysis by gender because female unemployment rates in Turkey are much higher than that of males. For instance the unemployment rate was $9.6 \%$ for men and $13.7 \%$ for women in 2016. We also extend our investigation to the subsamples of the non-agricultural unemployment rate, and urban and rural unemployment rates. Employment in agriculture is rather high. About one in five people works in agriculture. Agriculture is dominated by small family farms. This causes agricultural unemployment to be small. For example the 
agricultural unemployment rate was $1.2 \%$ in 2011 . In contrast the non-agricultural unemployment rate $12.4 \%$ (10.2\% for men and $18.3 \%$ for women) in 2015 . Therefore it is appropriate to do a separate analysis of the non-agricultural unemployment rate as we do in this paper. The unemployment rates of urban and rural areas are also performed separately. The urban areas are those with a population of 20,000 and over and the rural areas are those with a population of less than 20,000. Finally we analyzed the youth unemployment rates. The age group of 15-24 has a particularly high unemployment rate in Turkey as it is in most countries. The unemployment rate for this group was $19.6 \%$ (17.4\% for men and $23.7 \%$ for women) in 2016.

There were several economic crises during the period considered. In 1991 the crisis was due to the Gulf war. In 1994 financial mismanagement caused a severe crisis. The delayed impact of the Asian and the Russian crises and the two severe earthquakes in Turkey took effect in 1999. A severe domestically produced crisis was felt in 2001. Finally, the effects of the global financial crisis were observed in Turkey in 2008-2009. The unemployment rate was $8.2 \%$ in $1991,8.6 \%$ in $1994,7.7 \%$ in 1999 and $10.3 \%$ in 2002. At the peak of the global crisis in 2009Q1 the unemployment rate was $16.1 \%$ with non-agricultural unemployment rate reaching 19.3\%. During the global crisis there were large employment losses due to economic decline and a cyclical increase in the labor force resulting in a large increase in unemployment. Next, a rapid decline in unemployment accompanied the high growth rate in 2011. Unemployment rate fell below the pre-crisis level. This was partly due to high growth rates and partly due to an unexpected increase in employment capacity creation of growth. Unemployment rate was at a low point in 2012Q2 but has been rising ever since with the more recent deterioration 
of the labor market conditions. Youth unemployment peaked with 24 percent in 2009Q2. It fell subsequently but it has also been rising more recently.

\section{Empirical Results}

The first thing we do in this section is to conduct unit root tests for the series under examination. The results, displayed in the Appendix, clearly provide evidence supporting the unit root hypothesis in all cases. Other unit root methods (Phillips and Perron, 1988; Elliot et al., 1996; Ng and Perron, 2001) produced essentially the same type of results. Next, in order to allow higher flexibility we consider the possibility of fractional integration and consider model $(2)$ with $\mathrm{z}_{\mathrm{t}}=(1, \mathrm{t})^{\mathrm{T}}$, i.e.,

$$
\mathrm{y}_{\mathrm{t}}=\beta_{1}+\beta_{2} \mathrm{t}+\mathrm{x}_{\mathrm{t}}, \quad(1-\mathrm{L})^{\mathrm{d}} \mathrm{x}_{\mathrm{t}}=\mathrm{u}_{\mathrm{t}}, \quad \mathrm{t}=1,2, \ldots .
$$

testing $H_{o}$ (1) for $d_{o}$-values from 0 to 2 with 0.01 increments. Table 2 displays for each series the values of $d_{o}$ producing the lowest statistic along with the $95 \%$ confidence of non-rejection values of $d$ supposing $u_{t}$ in (2) is a white noise process, and examining three different cases: i) with no deterministic terms, ii) with an intercept, and iii) with an intercept and a linear time trend.

We notice in Table 2 that an intercept seems to be sufficient to describe the deterministic components of the series since the time trend coefficients are found to be statistically insignificant in all cases. The estimated values of $\mathrm{d}$ are high, being above 0.5 (and thus showing nonstationarity) in all series. In fact, the unit root null hypothesis cannot be rejected in any series for the urban, non-agricultural, aggregate and youth unemployment data, and only for rural unemployment, this hypothesis is rejected in favor of mean reversion. Thus, we observe that urban unemployment is more persistent than 
rural unemployment and the estimates of $\mathrm{d}$ for male unemployment are higher than those for females in all cases examined. The order of integration for the aggregate data (Turkey) in the case of male unemployment is 1.26 , and the $\mathrm{I}(1)$ hypothesis is rejected in favor of higher orders of integration, while it is 0.97 in the case of female unemployment.

\section{[Insert Tables 2 and 3 about here]}

Allowing for autocorrelated disturbances throughout the exponential model of Bloomfield (1973), the estimated values of $d$ are displayed in Table 3. Generally, the values are smaller than in Table 2 and once more they are higher for males than for females in all the cases examined; however, for urban unemployment, the estimates are now smaller than for rural unemployment. Mean reversion now takes place for female unemployment in the case of non-agricultural, rural and young unemployment, and for the three cases (male, female and total) of urban unemployment.

Finally, we also conduct an alternative (semiparametric) estimation method (Robinson, 1995) that is basically a local Whittle approach in the frequency domain. Based on the potential nonstationary nature of the data, we conduct the analysis based on the first differenced data adding then a value 1 to the results obtained.

\section{[Insert Table 4 about here]}

Consistent with the parametric results, the estimated values of $d$ are higher than 0.5 in all cases. Once more they are higher in the case of male unemployment with mean reversion taking place in most cases for urban unemployment and also for rural and young 
female unemployment. Using other semiparametric methods based on both Whittle and log-periodogram regressions the results were almost identical to those reported here.

In the final part of this manuscript we examine the possibility of a non-linear structure underlying the Turkish unemployment rate. This is a relevant issue noting that fractional integration is very much related with the potential presence of non-linearities and breaks in the data. However, instead of assuming the presence of abrupt changes in the data, we consider a rather smooth change by using the Chebyshev polynomials in time. Cuestas and Gil-Alana (2016) has recently developed a procedure for fractional integration that allows non-linear deterministic trends based on the Chebyshev polynomials. In particular, they propose the following specification:

$$
\mathrm{y}_{\mathrm{t}}=\sum_{\mathrm{i}=0}^{\mathrm{m}} \theta_{\mathrm{i}} \mathrm{P}_{\mathrm{iT}}(\mathrm{t})+\mathrm{x}_{\mathrm{t}} ; \quad(1-\mathrm{L})^{\mathrm{d}} \mathrm{x}_{\mathrm{t}}=\mathrm{u}_{\mathrm{t}}, \quad \mathrm{t}=1,2, \ldots
$$

with $m$ indicating the order of the Chebyshev polynomial $P_{i, T}(t)$ defined as:

$$
\begin{gathered}
P_{0, T}(t)=1, \\
P_{i, T}(t)=\sqrt{2} \cos (i \pi(t-0.5) / T), \quad t=1,2, \ldots, T ; \quad i=1,2, \ldots .
\end{gathered}
$$

(see Hamming (1973) and Smyth (1998) for a detailed description of these polynomials). Bierens (1997) and Tomasevic et al. (2009) argue that it is possible to approximate highly non-linear trends with rather low degree polynomials. If $m=0$ the model contains an intercept, if $m=1$ it also includes a linear trend, and if $m>1$ it becomes non-linear - the higher $m$ is the less linear the approximated deterministic component becomes.

Across Tables 5 and 6 we display the estimates of $d$ in (5) along with the Chebyshev coefficients, imposing $\mathrm{m}=3$, and using white noise (Table 5) and autocorrelated (Table 6) errors. Thus, if the coefficients corresponding to $\theta_{2}$ and/or $\theta_{3}$ are 
statistically significantly different from zero we can conclude that the series display some non-linear structures.

\section{[Insert Tables 5 and 6 about here]}

Starting with the case of white noise errors, we observe little evidence for nonlinear behavior, and in those cases where it seems to take place, they occur for female unemployment in the three cases of non-agricultural, rural and urban unemployment. In addition, we also observe some (partial) non-linear pattern for total rural unemployment and young female unemployment where $\theta_{3}$ turns out to be significant but not $\theta_{2}$. However, allowing for autocorrelated errors, which seems more realistic, given its higher generalization, a different picture emerges and at least one non-linear coefficient is found to be statistically significant in all cases. Nevertheless, similar to the previous case, stronger evidence of non-linear behavior is observed for female unemployment rates in all cases examined. Focusing now on the orders of integration, we observe in Table 6 that for the aggregated series (Turkey) the I(1) hypothesis cannot be rejected for male unemployment. At the other extreme the $\mathrm{I}(0)$ hypothesis cannot be rejected for female unemployment and both hypothesis are rejected in favor of $0<\mathrm{d}<1$ in case of total unemployment. Similar evidence is obtained for the non-agricultural and young unemployment series, though here in the case of total unemployment the I(1) hypothesis cannot be rejected. Finally, mean reversion (i.e. $\mathrm{d}<1$ ) is obtained in the six series corresponding to rural and urban unemployment. In the rural case, the $\mathrm{I}(0)$ null cannot be rejected for female unemployment, though it is rejected in favor of long memory $(\mathrm{d}>$ 0 ) in the other two series. However, for urban unemployment the $\mathrm{I}(0)$ hypothesis cannot be rejected in any of the three series. 
In short the results imply that the unemployment series of Turkey has longmemory while Turkey male unemployment is non-stationary and Turkey female unemployment is stationary. These results are similar for the non-agricultural unemployment rates, indicating that non-agricultural unemployment rates dominate the unemployment rates of Turkey. With regards to rural and urban series we find meanreversion. For rural and urban females we find stationarity. While for rural male and rural total we find long-memory and for urban male and urban total we find stationarity. More clearly, for three of the urban series (male, female and total) we find stationarity while for rural female we also find stationarity. But, for rural male and rural total we find longmemory. In other words, the female unemployment series (Turkey, non-agricultural, rural and urban) are all unambiguously stationarity. Male unemployment series is nonstationary in the cases of Turkey, non-agricultural and rural unemployment while it is stationarity in the case of urban male unemployment. The unemployment rate for Turkey indicates that in the case of total Turkey, non-agricultural total and rural total unemployment series have long-memory but in the case of rural total unemployment it is stationary.

The union density is rather low in Turkey with about 6.3 percent compared to the OECD average of about 17 percent and has been declining over time (OECD, 2017). Collective bargaining is fairly non-centralized and covers only union workers. Employment protection legislation instituted recently is considered to be stronger than most countries but covers only large firms which form only a small portion. Unemployment insurance has also only been recently introduced and covers only a small portion of the unemployed. Therefore, Turkish Labor market can be considered to be 
characterized by weak institutionalization and low enforcement. These features explain the long-memory we found in the total and non-agricultural unemployment rates. Furthermore, the percentage of those who are unemployed for a duration of one year and over (long-term unemployed) in 2015 was 21.2 percent (17.7 percent for males and 26.8 percent for females) compared to the OECD average of 33.8 percent (OECD, 2017). Given that the long-term unemployed is lower than the OECD countries, this could imply that the long term unemployed do not suffer any particular social stigma of the. This may also contribute to the long-memory we found in the total and non-agricultural unemployment rates. As remarked upon earlier and as pointed out by Cross (1995) the existence of heterogeneous agents explains the hysteresis effect. However, the Turkish Labor market cannot be considered to be composed of highly heterogeneous agents. As remarked earlier non-agricultural unemployment rate is much higher than the agricultural unemployment rate and exhibits a time pattern highly responsive to business cycles. Unpaid family work and self-employment determine employment patterns in the agricultural sector. In the non-agricultural sector wage employment prevails. Given the major institutional characteristics of the Turkish Labor market and the conclusions of this paper we can speculate on the results of active labor market policies which have been recently implemented by the Turkish Government. The Turkish government started a subsidy program in 2008 to generate new employment for younger men and all women, these being the two groups with notably higher unemployment rates, as discussed earlier in Section 5. Balkan et al. (2016) show that the 2008 subsidy policies have been effective in increasing the employment probability of older unskilled woman. Currently, the government is implementing a program with the aim of generating employment for over two million people throughout 2017. The success of these programs depend on findings of hysteresis in the unemployment rates. 


\section{Conclusions}

In this paper we have examined the time series behavior of various series corresponding to the unemployment rate in Turkey. Our purpose was to estimate the order of integration of the series in order to determine which hypothesis among those existing in the literature (i.e., NAIRU, structuralist, persistence and hysteresis) was more appropriate for the data examined (quarterly from 1988Q3 to 2013Q4). Previous studies used linear and nonlinear unit root tests and standard long memory methods to investigate these issues with regard to Turkish unemployment series. However, these studies did not consider both the non-linear symptoms and long memory processes. To the best of our knowledge, this is the first article which analyzes simultaneously both the non-linear dynamics and fractional integration utilizing the method of Cuestas and Gil-Alana (2016). Considering this approach in the case of Turkish unemployment series is the main contribution in this work. Our results indicate that the unemployment series in Turkey is highly persistent, with orders of integration equal to or higher than 1 in the majority of cases, implying permanency of the shocks and a lack of mean reversion. In fact, the only evidence in favor of mean reversion is obtained in the case of female unemployment and this happens for the four groups examined, corresponding to non-agricultural, rural, urban and young unemployment. With regard to the possibility of non-linearities, again this only takes place in case of female unemployment. An important policy implication of our empirical results is that the labor and macroeconomic policies are likely to have long lasting effects on the unemployment rates in Turkey. 


\section{References}

Abadir, K. M., Distasso, W. and Giraitis L. (2007) An I(d) model with trend and cycles, Journal of Econometrics, 163, 186-199.

Akcay, S. (2013) The Unemployment Hysteresis Analysis For Turkey, MA degree thesis Middle East Technical University, Ankara, Turkey.

Akdogan, K. (2015) Unemployment Hysteresis and Structural Change in Europe, Mimeo. Central Bank of Turkey, Ankara.

Arestis, P. and Mariscal, I. B. F. (1999) Unit roots and structural breaks in OECD unemployment, Economics Letters, 65, 149-156.

Balkan, B., Baskaya, Y. S. S., and Tumen, S. (2016). Evaluating the impact of the post2008 employment subsidy program in Turkey, IZA Discussion Paper No. 9993 Bonn, Germany.

Baillie, R. T. and Morana, C. (2009) Modelling long memory and structural breaks in conditional variances: An adaptive FIGARCH approach, Journal of Economic Dynamics and Control, 33(8), 1577-1592.

Barişik, S. and Çevik, E. I. (2008) İşsizlikte Histeri Etkisi: Uzun Hafiza Modelleri, KamuIş, 9 (4), 1-36.

Barro, R. (1988) The natural rate theory reconsidered: The persistence of unemployment, American Economic Review, 78, 32-37.

Bayat T., Kayhan, S. and Koçyiğit, A. (2013) Türkiye'de İşsizliğin Asimetrik Davranışının Rejim Değişim Modeliyle İncelenmesi, Business and Economics Research Journal, 4 (2).

Bayrakdar, S. (2015) Türkiye için Issizlik Histerisi Ya Da Doğal Issizlik Orani Hipotezinin Geçerliliginin Sinanmasi, Journal of Economic Policy Researches, 2 (2), 45-61.

Bianchi, M. and Zoega, G. (1998) Unemployment persistence: Does the size of the shock matter? Journal of Applied Econometrics, 13, 283-304.

Bierens, H. J. (1997) Testing the unit root with drift hypothesis against nonlinear trend stationarity with an application to the US price level and interest rate, Journal of Econometrics, 81, 29-64.

Bildirici M., Özgür, O. E., Turkmen, C. and Yalcinkaya, Y. (2012) The Persistence Effect of Unemployment In Turkey: An Analysis of the 1980-2010 Period, The Journal of Business Economics and Finance, 1 (3), 22-32. 
Blanchard, O. J. and Summers, L. H. (1986) Hysteresis and the European unemployment, NBER Working Paper series no. 1950.

Blanchard, O. J. and Summers, L. H. (1987) Hysteresis and unemployement, European Economic Review, 31, 288-295.

Bloomfield, P. (1973) An exponential model in the spectrum of a scalar time series. Biometrika, 60, 217-226.

Brunello, G. (1990) Hysteresis and 'the Japanese unemployment problem': a preliminary investigation, Oxford Economic Papers, 43, 483-500.

Caporale, G. M. and Gil-Alana, L. A. (2007) Non-linearities and fractional integration in the US unemployment rate, Oxford Bulletin of Economics and Statistics, 69, 521544.

Caporale, G. M. and Gil-Alana, L. A. (2008) Modelling the US, UK and Japanese unemployment rates: Fractional integration and structural changes, Computational Statistics and Data Analysis, 52, 4998-5013.

Chien-Chiang, L. and Chun-Ping, C. (2008) Unemployment hysteresis in OECD countries: Centurial time series evidence with structural breaks, Economic Modelling, 25, 312-325.

Chow, G. and Lin, A. (1971) Best linear unbiased interpolation, distribution, and extrapolation of time series by related series, The Review of Economics and Statistics, 372-375.

Christopoulos, D. and León-Ledesma, M. A. (2007) Unemployment hysteresis in EU countries: what do we really know about it?, Journal of Economic Studies, 34, 8089.

Cınar, M., Akay, H. K. and Y1lmaz, F. (2014) A Sectoral Analysis of Hysteresis in Unemployment: Evidence from Turkey, Bilig ,69, 29-52.

Clark, A. (2003) Unemployment as a social norm: psychological evidence from panel data, Journal of Labor Economics, 21, 323-351.

Cross, R. (1995) Is the natural state hypothesis consistent with hysteresis, in Cross, R. The natural rate of unemployment, Cambridge University Press, Massachusets.

Cuestas, J. C., and Ordóñez, J. (2011) Unemployment and common smooth transition trends in Central and Eastern European Countries, Economic Issues, 16(2), 39-52.

Cuestas, J .C. and Gil-Alana, L. A. (2016) A Non-Linear Approach with Long Range Dependence Based on Chebyshev Polynomials, Studies in Nonlinear Dynamics and Econometrics, 20(1), 57-94. 
Dickey, D. A., and Fuller, W. A. (1979) Distribution of the estimators for autoregressive time series with a unit root, Journal of the American Statistical Association, 7, 427431 .

Elliot G, Rothenberg T. J. and Stock, J. H. (1996) Efficient Tests for an Autoregressive Unit Root, Econometrica, 64, 813-836

Ener, M. and Arıca, F. (2011a) Unemployment Hysteresis in Turkey and 15 EU Countries: A Panel Approach, Research Journal of Economics, 1, 65-71.

Ener, M. and Arica, F. (2011b) Is There Hysteresis In Unemployment In OECD Countries? Evidence from Panel Unit Root Test With Structural Breaks, Chinese Business Review, 10, 294-304.

Ewing, B. T. and Wunnava, P. V. (2001) Unit roots and structural breaks in North American unemployment rates, North American Journal of Economics and Finance, $12,273-282$.

Gil-Alana, L. A. (2001a) A fractionally integrated exponential model for UK unemployment, Journal of Forecasting, 20, 329-340.

Gil-Alana, L. A. (2001b) The persistence of unemployment in the USA and Europe in terms of fractionally ARIMA models, Applied Economics, 33, 1263-1269.

Gil-Alana, L. A. (2002) Structural breaks and fractional integration in the US output and unemployment rate, Economics Letters, 77, 79-84.

Gil-Alana, L. A. (2008) Fractional integration and structural breaks at unknown periods of time, Journal of Time Series Analysis, 29, 163-185.

Gil-Alana, L. A. and Robinson, P. M. (1997) Testing of unit root and other nonstationary hypotheses in macroeconomic time series. Journal of Econometrics, 80(2), 241-268.

Gomez, Z. and Maravall , A. (1996) Program Tramo and Seats: Instructions for the Users, Working Paper 9628, Bank of Spain.

Gözgör, G. (2012) Hysteresis in Regional Unemployment Rates in Turkey, International Journal of Economics and Finance, 4 (9), 175-181.

Gözgör, G. (2013) Unemployment Persistence and Inflation Convergence: Evidence from Regions of Turkey, Regional and Sectoral Economic Studies, 13(1).

Güloğlu, B. and İspir, M. S. (2011) Is the Natural Unemployment or Hysteresis? SectorSpecific Panel Unit Root Test Analysis for Turkey, Ege Academic Review, 11(2), 205-215.

Hamming, R. W. (1973) Numerical Methods for Scientists and Engineers, Dover 
Khraief, N., Shahbaz, M., Heshmati, A. and Azam, M. (2015) Are Unemployment Rates in OECD Countries Stationary? Evidence from Univariate and Panel Unit Root Tests, Institute for the Study of Labor (IZA) Working Paper No: 9571, Bonn, Germany.

Koçyiğit, A., Bayat, T. and Tüfekçi, A. (2011) Turkiye' de Issizlik Histerisi ve STAR Model Uygulamasi, Marmara Üniversitesi Iktisadi Idari Bilimler Fakultesi Dergisi, 31(2), 45-60.

Küçükkale, Y. (2001) Doğal işsizlik Oranındaki Keynesyen Histeri üzerine Klasik Bir İnceleme: Kalman Filtre Tahmin Tekniği ile Türkiye Örneği 1950-1995, Paper presented at 19-22 September, 2001 Çukurova University, V. National Econometrics and Statistics Symposium.

Layard, R., Nickell, S. and Jackman, R. (2005) Unemployment: macroeconomic performance and the labor market, Oxford University Press, Oxford.

León-Ledesma, M. A. (2002) Unemployment hysteresis in the US and the EU: A panel data approach, Bulletin of Economic Research, 54, 95-105.

Lobato and Velasco, (2007) Efficient Wald Tests for Fractional Unit Roots, Econometrica, 75(2), 575-589.

Mitchell, W. F. (1993) Testing for unit roots and persistence in OECD unemployment rates, Applied Economics, 25, 1489-1501.

Moghaddasi, R. and Raini, A. G. N. (2015) Structural Break and Unit Root in Unemployment of Selected Eco Members, Spectrum: A Journal of Multidisciplinary Research, 4(1), 28-44.

Nelson, C. R. and Plosser, C. I. (1982) Trends and random walks in macroeconomic time series, Journal of Monetary Economics, 10, 139-169.

Ng. S. and Perron, P. (2001), Lag Length Selecsion and the Construction of Unit Root Tests with Good Size and Power, Econometrica, 69(6), 1519-1554.

OECD (2017) OECD.Stat Extracts. available at: http://stats.oecd.org/ (Accesed in April 2017).

Özcan, B. (2012) İşsizlik Histerisi Hipotezi OECD Ülkeleri İçin Geçerli mi? Yapısal Kırılmalı Birim Kök Analizi, Erciyes Üniversitesi Iktisadi ve Idari Bilimler Fakültesi Dergisi, 40, 98-108.

Papell, D. H., Murray, C. J. and Ghiblawi, H. (2000) The structure of unemployment, Review of Economics and Statistics, 82, 309-315.

Pazarlıoğlu, M. V. and Çevik, İ. (2007) Ratchet Model Uygulaması: Türkiye Örneği, Süleyman Demirel Üniversites Iktisadi ve Idari Bilimler Fakültes Dergisi, 12(2), 4151. 
Perron, P. (1989) The great crash, the oil price shock, and the unit root hypothesis, Econometrica, 57, 1361-1401.

Phelps, E. S. (1972) Inflation policy and unemployment theory: the cost-benefit approach to monetary planning, Norton, New York.

Phillips, P.C.B., and Perron, P. (1988) Testing for a unit root in a time series regression, Biometrika, 75, 335-346.

Phillips, P.C.B. and Xiao, Z. (1999) A primer on unit root testing, Journal of Economic Surveys, 12, 423-470.

Robinson, P. M. (1994), Statistical inference for a random coefficient autoregressive model, Scandinavian Journal of Statistics, 5, 163-168.

Robinson, P. M. (1995), Gaussian semi-parametric estimation of long range dependence, Annals of Statictics, 23, 1630-1661.

Roed, K. (1996) Unemployment hysteresis - macroevidence from 16 OECD countries, Empirical Economics, 21, 589-600.

Sibbertsen, T. (2004), Long memory versus structural breaks: An overview, Statistical Papers, 45(4), 465-515.

Skalin, J. and Teräsvirta, T. (2002) Modelling asymmetries and moving equilibria in unemployment rates, Macroeconomic Dynamics, 6, 202-241.

Smyth, G. K. (1998) Polynomial Approximation, John Wiley \& Sons, Ltd, Chichester.

Song, F. M. and Wu, F. (1997) Hysteresis in Unemployment Evidence from 48 U.S. States, Economic Inquiry, 35, 235-243.

Song, F. M. and Wu, F. (1998) Hysteresis in unemployment: evidence from OECD countries, The Quarterly Review of Economics and Statistics, 38, 181-192.

Strazicich, M. C., Tieslau, M. and Lee, J. (2001) Hysteresis in Unemployment? Evidence from Panel Unit Root Tests with Structural Change, manuscript, University of North Texas.

Tokatlıŏlu, I., Öztürk, F. and Ardor, H. N. (2014) Hysteresis Effect in Selected EU Countries and Turkey Labor Market: Ratchet Model Analysis, Sosyoekonomi, 20142 (July-December): 297-320.

Tomasevic, N. M. and Stanivuk, T. (2009) Regression Analysis and aproximation by means of Chebyshev Polynomial, Informatologia, 42,(3), 166-172.

Tunal1, H. (2010) The Analysis of Unemployment in Turkey: Some Empirical Evidence Using Co-Integration Test, European Journal of Social Sciences, 18(1), 18-38. 
Yiğit Ö. and Gökçe, A. (2012) Türkiye Ekonomisi Için NAIRU Tahmini, Ekonomik Yaklasim,23, 83-93.

Yilanci, V. (2008) Are unemployment rates nonstationary or nonlinear? Evidence from 19 OECD countries, Economics Bulletin, 3, 1-5.

Yilanci, V. (2009) Analyzing the Unemployment Hysteresis for Turkey Under Structural Breaks, Dogus Üniversitesi Dergisi, 10(2), 324-335.

Yıldırım, S. (2011) Türkiye' de Histeri Hipotezinin Geçerliliğinin Çoklu Yapısal Kırılmalı CKP Birim Kök Testiyle Sınanması, Akdeniz Iktisadi Idari Bilimler Fakultesi Dergisi, 22, 28-47. 
Table 1: Order of integration of unemployment and hypothesis fulfilled

\begin{tabular}{|c|c|}
\hline Order of integration & Hypothesis \\
\hline$d \in(0,0.5)$ & NAIRU \\
\hline$d \in(0,0.5)+$ Structural Changes & Structuralist viewpoint \\
\hline$d \in[0.5,1)$ & Persistence \\
\hline$d \geq 1$ & Hysteresis \\
\hline
\end{tabular}


Table 2: Estimates of d based on white noise disturbances

\begin{tabular}{|c|c|c|c|c|}
\hline & & No regressors & An intercept & A linear time trend \\
\hline \multirow{3}{*}{ TURKEY } & Male & $1.05(0.91,1.23)$ & $1.26(1.09,1.50)$ & $1.26(1.09,1.50)$ \\
\hline & Female & $0.94(0.79,1.15)$ & $0.97(0.83,1.16)$ & $0.96 \quad(0.82,1.16)$ \\
\hline & Total & $1.02(0.87,1.21)$ & $1.13(0.95,1.39)$ & $1.13(0.95,1.39)$ \\
\hline \multirow{3}{*}{$\begin{array}{c}\text { Non- } \\
\text { Agricult. }\end{array}$} & Male & $0.99(0.86,1.16)$ & $1.11(0.95,1.33)$ & $1.11(0.95,1.33)$ \\
\hline & Female & $0.91(0.78,1.10)$ & $0.85(0.66,1.08)$ & $0.87 \quad(0.73,1.07)$ \\
\hline & Total & $0.97(0.84,1.15)$ & $1.11(0.94,1.32)$ & $1.11(0.94,1.32)$ \\
\hline \multirow{3}{*}{ Rural } & Male & $0.89(0.76,1.05)$ & $0.81(0.69,0.98)^{*}$ & $0.81 \quad(0.69,0.98)$ \\
\hline & Female & $0.87(0.71,1.09)$ & $0.74(0.62,0.91)^{*}$ & $0.74(0.61,0.91)$ \\
\hline & Total & $0.88(0.74,1.06)$ & $0.79(0.68,0.96)^{*}$ & $0.79 \quad(0.67,0.96)$ \\
\hline \multirow{3}{*}{ Urban } & Male & $1.02(0.88,1.22)$ & $1.13(0.93,1.41)$ & $1.13(0.93,1.41)$ \\
\hline & Female & $0.93(0.80,1.11)$ & $0.84 \quad(0.67,1.06)$ & $0.85 \quad(0.70,1.06)$ \\
\hline & Total & $0.99(0.85,1.32)$ & $1.06(0.87,1.32)$ & $1.06(0.87,1.32)$ \\
\hline \multirow{3}{*}{ Youth } & Male & $1.00(0.86,1.20)$ & $1.04(0.88,1.26)$ & $1.04(0.88,1.26)$ \\
\hline & Female & $0.88 \quad(0.73,1.10)$ & $0.87 \quad(0.74,1.07)$ & $0.86 \quad(0.72,1.07)$ \\
\hline & Total & $0.98 \quad(0.83,1.18)$ & $1.05(0.89,1.26)$ & $1.05(0.89,1.26)$ \\
\hline
\end{tabular}

In bold the selected models according to the deterministic terms. " * " indicates evidence of mean reversion at the $5 \%$ level. 
Table 3: Estimates of d based on autocorrelated disturbances

\begin{tabular}{|c|c|c|c|c|}
\hline & & No regressors & An intercept & A linear time trend \\
\hline \multirow{3}{*}{ TURKEY } & Male & $0.95(0.64,1.38)$ & $0.84(0.58,1.29)$ & $0.84(0.57,1.29)$ \\
\hline & Female & $0.81 \quad(0.49,1.23)$ & $0.66(0.48,1.01)$ & $0.66(0.41,1.01)$ \\
\hline & Total & $0.71(0.44,1.10)$ & $0.79(0.60,1.12)$ & $0.77 \quad(0.53,1.12)$ \\
\hline \multirow{3}{*}{$\begin{array}{c}\text { Non- } \\
\text { Agricult. }\end{array}$} & Male & $0.93(0.64,1.32)$ & $0.80(0.46,1.29)$ & $0.80 \quad(0.46,1.29)$ \\
\hline & Female & $0.75 \quad(0.52,1.04)$ & $0.46(0.31,0.93)^{*}$ & $0.67 \quad(0.42,0.93)$ \\
\hline & Total & $0.87(0.61,1.24)$ & $0.81(0.46,1.31)$ & $0.80 \quad(0.49,1.32)$ \\
\hline \multirow{3}{*}{ Rural } & Male & $0.84 \quad(0.52,1.18)$ & $0.70(0.51,1.02)$ & $0.69 \quad(0.47,1.02)$ \\
\hline & Female & $0.61(0.36,1.01)$ & $0.68(0.48,0.96)^{*}$ & $0.65 \quad(0.40,0.97)$ \\
\hline & Total & $0.78 \quad(0.47,1.19)$ & $0.72(0.53,1.02)$ & $0.70 \quad(0.48,1.02)$ \\
\hline \multirow{3}{*}{ Urban } & Male & $0.82(0.53,1.21)$ & $0.55(0.31,0.90)^{*}$ & $0.53(0.27,0.90)$ \\
\hline & Female & $0.85(0.60,1.16)$ & $0.54(0.37,0.90)^{*}$ & $0.65(0.47,0.93)$ \\
\hline & Total & $0.84(0.54,1.22)$ & $0.55(0.31,0.92)^{*}$ & $0.56(0.29,0.91)$ \\
\hline \multirow{3}{*}{ Youth } & Male & $0.80 \quad(0.48,1.17)$ & $0.76(0.48,1.18)$ & $0.76(0.46,1.18)$ \\
\hline & Female & $0.63(0.38,1.02)$ & $0.70(0.56,0.95)^{*}$ & $0.66(0.39,0.94)$ \\
\hline & Total & $0.75 \quad(0.42,1.16)$ & $0.75(0.52,1.12)$ & $0.74(0.45,1.12)$ \\
\hline
\end{tabular}

In bold the selected models according to the deterministic terms. " * " indicates evidence of mean reversion at the $5 \%$ level. 
Table 4: Semiparametric estimates of $d$

\begin{tabular}{|c|c|c|c|c|c|c|c|c|c|}
\hline \multirow{4}{*}{ TURKEY } & & 10 & 11 & 12 & 15 & 20 & 25 & 30 & 40 \\
\hline & Male & 0.733 & 0.840 & 0.953 & 0.961 & 1.027 & 1.238 & 1.286 & 1.222 \\
\hline & Female & 0.863 & 0.844 & 0.922 & 0.825 & 0.923 & 0.991 & 1.108 & 0.921 \\
\hline & Total & 0.705 & 0.800 & 0.830 & 0.887 & 0.958 & 0.999 & 1.058 & 1.081 \\
\hline \multirow{4}{*}{$\begin{array}{c}\text { Non - } \\
\text { agricult. }\end{array}$} & Male & 0.573 & 0.672 & 0.776 & 0.927 & 0.994 & 1.177 & 1.156 & 1.100 \\
\hline & Female & 0.919 & $0 . \ddot{8899}$ & 0.962 & 0.766 & 0.740 & 0.847 & 0.930 & 0.857 \\
\hline & Total & 0.604 & 0.681 & 0.776 & 0.881 & 0.957 & 1.184 & 1.177 & 1.115 \\
\hline & Male & 0.933 & 0.966 & 0.878 & 0.862 & 0.932 & 0.868 & 0.845 & $0.813 *$ \\
\hline \multirow[t]{3}{*}{ Rural } & Female & 0.622 & 0.677 & 0.724 & 0.759 & 0.696 & 0.777 & 0.843 & $0.741 *$ \\
\hline & Total & $0 . \ddot{914}$ & $0 . \ddot{929}$ & $0 . \ddot{853}$ & 0.841 & 0.884 & 0.893 & 0.848 & $0.789 *$ \\
\hline & Male & 0.640 & 0.676 & 0.772 & 0.735 & 0.788 & 0.929 & 1.067 & 1.068 \\
\hline \multirow[t]{3}{*}{ Urban } & Female & 0.829 & 0.752 & 0.686 & 0.662 & 0.733 & 0.809 & 0.912 & 0.854 \\
\hline & Total & 0.636 & 0.648 & 0.716 & 0.738 & 0.786 & 0.909 & 1.051 & 1.020 \\
\hline & Male & 0.778 & 0.895 & 0.986 & 0.817 & 0.804 & 0.859 & 0.897 & 0.912 \\
\hline \multirow[t]{2}{*}{ Youth } & Female & 0.846 & 0.767 & 0.792 & 0.581 & 0.600 & 0.633 & 0.639 & 0.656 \\
\hline & Total & 0.911 & 0.941 & 1.005 & 0.707 & 0.751 & 0.801 & 0.811 & 0.847 \\
\hline \multicolumn{2}{|c|}{ Lower $5 \%$. } & 0.739 & 0.752 & 0.762 & 0.787 & 0.816 & 0.835 & 0.849 & 0.869 \\
\hline \multicolumn{2}{|c|}{ Upper 5\% } & 1.260 & 1.247 & 1.237 & 1.212 & 1.183 & 1.164 & 1.150 & 1.130 \\
\hline
\end{tabular}

In bold the models that correspond approximately at $\mathrm{m}=(\mathrm{T})^{0.5}$; “* “ indicates evidence of mean reversion at the $5 \%$ level. 
Table 5: Estimates based on a non-linear $I(d)$ model with white noise errors

\begin{tabular}{|c|c|c|c|c|c|c|}
\hline Seri & & d & $\theta_{0}$ & $\theta_{1}$ & $\theta_{2}$ & $\theta_{3}$ \\
\hline \multirow{4}{*}{ TURKEY } & Male & $\begin{array}{c}1.24 \\
(1.06,1.45)\end{array}$ & $\begin{array}{c}7.3299 \\
(1.74)\end{array}$ & $\begin{array}{c}-0.9482 \\
(-0.21)\end{array}$ & $\begin{array}{l}0.3415 \\
(0.20)\end{array}$ & $\begin{array}{l}0.8059 \\
(0.78)\end{array}$ \\
\hline & Female & $\begin{array}{c}0.89 \\
(0.70,1.13)\end{array}$ & $\begin{array}{c}10.2818 \\
(4.19)\end{array}$ & $\begin{array}{c}-1.5347 \\
(-1.07)\end{array}$ & $\begin{array}{l}0.9354 \\
(1.16)\end{array}$ & $\begin{array}{l}0.6428 \\
(1.14)\end{array}$ \\
\hline & Total & $\begin{array}{c}1.10 \\
(0.90,1.37)\end{array}$ & $\begin{array}{c}8.2528 \\
(1.80)\end{array}$ & $\begin{array}{c}-1.1581 \\
(-0.41)\end{array}$ & $\begin{array}{c}0.4250 \\
(0.34)\end{array}$ & $\begin{array}{l}0.7352 \\
(0.92)\end{array}$ \\
\hline & Male & $\begin{array}{c}1.10 \\
(0.93,1.32)\end{array}$ & $\begin{array}{c}9.6951 \\
(1.68)\end{array}$ & $\begin{array}{c}-0.3072 \\
(-0.08)\end{array}$ & $\begin{array}{c}0.3069 \\
(0.19)\end{array}$ & $\begin{array}{l}0.8060 \\
(0.80)\end{array}$ \\
\hline \multirow{3}{*}{$\begin{array}{l}\text { Non- } \\
\text { agricult. }\end{array}$} & Female & $\begin{array}{c}0.81 \\
(0.61,1.05)\end{array}$ & $\begin{array}{c}23.2414 \\
(6.03)\end{array}$ & $\begin{array}{c}2.9696 \\
(1.35)\end{array}$ & $\begin{array}{c}2.1122 \\
(1.65)\end{array}$ & $\begin{array}{l}1.5165 \\
(1.53)\end{array}$ \\
\hline & Total & $\begin{array}{c}1.08 \\
(0.91,1.31)\end{array}$ & $\begin{array}{c}12.6247 \\
(2.29)\end{array}$ & $\begin{array}{c}-0.0744 \\
(-0.02)\end{array}$ & $\begin{array}{l}0.6069 \\
(0.39)\end{array}$ & $\begin{array}{l}0.8481 \\
(0.86)\end{array}$ \\
\hline & Male & $\begin{array}{c}0.75 \\
(0.61,0.95)\end{array}$ & $\begin{array}{l}5.9275 \\
(4.16)\end{array}$ & $\begin{array}{c}-0.9860 \\
(-1.22)\end{array}$ & $\begin{array}{c}0.3450 \\
(0.64)\end{array}$ & $\begin{array}{l}0.6075 \\
(1.53)\end{array}$ \\
\hline \multirow[t]{3}{*}{ Rural } & Female & $\begin{array}{c}0.63 \\
(0.45,0.86)\end{array}$ & $\begin{array}{l}3.5316 \\
(4.99)\end{array}$ & $\begin{array}{c}-0.5605 \\
(-1.39)\end{array}$ & $\begin{array}{c}0.51712 \\
(1.77)\end{array}$ & $\begin{array}{l}0.3565 \\
(1.65)\end{array}$ \\
\hline & Total & $\begin{array}{c}0.71 \\
(0.56,0.92)\end{array}$ & $\begin{array}{l}5.1940 \\
(5.04)\end{array}$ & $\begin{array}{c}-0.8925 \\
(-1.53)\end{array}$ & $\begin{array}{c}0.3935 \\
(0.98)\end{array}$ & $\begin{array}{c}0.5189 \\
(1.71)\end{array}$ \\
\hline & Male & $\begin{array}{c}1.11 \\
(0.89,1.39)\end{array}$ & $\begin{array}{c}8.8066 \\
(1.73)\end{array}$ & $\begin{array}{c}-0.6599 \\
(-0.17)\end{array}$ & $\begin{array}{l}0.0752 \\
(0.04)\end{array}$ & $\begin{array}{c}0.8200 \\
(0.77)\end{array}$ \\
\hline \multirow[t]{3}{*}{ Urban } & Female & $\begin{array}{c}0.77 \\
(0.55,1.03)\end{array}$ & $\begin{array}{c}19.9600 \\
(6.99)\end{array}$ & $\begin{array}{c}2.1989 \\
(1.33)\end{array}$ & $\begin{array}{c}1.8220 \\
(1.71)\end{array}$ & $\begin{array}{c}1.3380 \\
(1.71)\end{array}$ \\
\hline & Total & $\begin{array}{c}1.03 \\
(0.83,1.31)\end{array}$ & $\begin{array}{c}11.4800 \\
(2.37)\end{array}$ & $\begin{array}{c}-0.3920 \\
(-0.13)\end{array}$ & $\begin{array}{c}0.3888 \\
(0.27)\end{array}$ & $\begin{array}{l}0.8397 \\
(0.91)\end{array}$ \\
\hline & Male & $\begin{array}{c}1.01 \\
(0.85,1.24)\end{array}$ & $\begin{array}{c}16.2067 \\
(2.56)\end{array}$ & $\begin{array}{c}-1.1655 \\
(-0.30)\end{array}$ & $\begin{array}{c}0.3059 \\
(0.16)\end{array}$ & $\begin{array}{l}1.2478 \\
(1.00)\end{array}$ \\
\hline \multirow[t]{2}{*}{ Youth } & Female & $\begin{array}{c}0.76 \\
(0.55,1.03)\end{array}$ & $\begin{array}{c}17.9718 \\
(6.39)\end{array}$ & $\begin{array}{c}-3.0456 \\
(-1.91)\end{array}$ & $\begin{array}{l}1.2579 \\
(1.21)\end{array}$ & $\begin{array}{c}1.1183 \\
(1.75)\end{array}$ \\
\hline & Total & $\begin{array}{c}1.01 \\
(0.83,1.25)\end{array}$ & $\begin{array}{c}17.2244 \\
(3.05)\end{array}$ & $\begin{array}{c}-1.9012 \\
(-0.56)\end{array}$ & $\begin{array}{l}0.5987 \\
(0.35)\end{array}$ & $\begin{array}{l}1.1811 \\
(1.06)\end{array}$ \\
\hline
\end{tabular}


Table 6: Estimates based on a non-linear I(d) model with autocorrelated errors

\begin{tabular}{|c|c|c|c|c|c|c|}
\hline Seric & & d & $\theta_{0}$ & $\theta_{1}$ & $\theta_{2}$ & $\theta_{3}$ \\
\hline \multirow{4}{*}{ TURKEY } & Male & $\begin{array}{c}0.72 \\
(0.25,1.24)\end{array}$ & $\begin{array}{c}8.2283 \\
(7.53)\end{array}$ & $\begin{array}{c}-1.1149 \\
(-1.80)\end{array}$ & $\begin{array}{l}0.1015 \\
(0.24)\end{array}$ & $\begin{array}{l}0.7595 \\
(2.37)\end{array}$ \\
\hline & Female & $\begin{array}{c}0.29 \\
(-0.31,0.95)\end{array}$ & $\begin{array}{l}9.4500 \\
(34.12)\end{array}$ & $\begin{array}{c}-1.5477 \\
(-7.86)\end{array}$ & $\begin{array}{c}0.9195 \\
(5.27)\end{array}$ & $\begin{array}{l}0.6536 \\
(4.13)\end{array}$ \\
\hline & Total & $\begin{array}{c}0.39 \\
(0.00,0.88)\end{array}$ & $\begin{array}{l}8.9994 \\
(24.35)\end{array}$ & $\begin{array}{c}-1.2257 \\
(-5.13)\end{array}$ & $\begin{array}{c}\mathbf{0 . 3 4 3 5} \\
(1.69)\end{array}$ & $\begin{array}{l}0.7129 \\
(4.03)\end{array}$ \\
\hline & Male & $\begin{array}{c}0.72 \\
(0.25,1.24)\end{array}$ & $\begin{array}{c}10.4812 \\
(7.32)\end{array}$ & $\begin{array}{c}-0.4253 \\
(-0.52)\end{array}$ & $\begin{array}{l}0.1165 \\
(0.21)\end{array}$ & $\begin{array}{c}0.7725 \\
(1.86)\end{array}$ \\
\hline \multirow{3}{*}{$\begin{array}{l}\text { Non- } \\
\text { agricult. }\end{array}$} & Female & $\begin{array}{c}0.96 \\
(-0.45,0.78)\end{array}$ & $\begin{array}{c}20.3609 \\
(82.27)\end{array}$ & $\begin{array}{l}2.5333 \\
(11.02)\end{array}$ & $\begin{array}{c}1.9399 \\
(8.65)\end{array}$ & $\begin{array}{l}1.3940 \\
(6.34)\end{array}$ \\
\hline & Total & $\begin{array}{c}0.64 \\
(0.16,1.28)\end{array}$ & $\begin{array}{c}12.7469 \\
(11.51)\end{array}$ & $\begin{array}{c}-0.0489 \\
(-0.07)\end{array}$ & $\begin{array}{l}0.5247 \\
(1.14)\end{array}$ & $\begin{array}{c}0.8548 \\
(2.38)\end{array}$ \\
\hline & Male & $\begin{array}{c}0.50 \\
(0.16,0.91)\end{array}$ & $\begin{array}{l}6.3702 \\
(11.34)\end{array}$ & $\begin{array}{c}-0.9755 \\
(-2.90)\end{array}$ & $\begin{array}{c}0.3240 \\
(1.20)\end{array}$ & $\begin{array}{c}0.6012 \\
(2.68)\end{array}$ \\
\hline \multirow[t]{3}{*}{ Rural } & Female & $\begin{array}{c}0.15 \\
(-0.35,0.78)\end{array}$ & $\begin{array}{l}3.2519 \\
(29.49)\end{array}$ & $\begin{array}{c}-0.5891 \\
(-6.41)\end{array}$ & $\begin{array}{c}\mathbf{0 . 4 6 2 7} \\
(5.36)\end{array}$ & $\begin{array}{c}0.3532 \\
(4.30)\end{array}$ \\
\hline & Total & $\begin{array}{c}0.45 \\
(0.08,0.91)\end{array}$ & $\begin{array}{r}5.3507 \\
(13.76)\end{array}$ & $\begin{array}{c}-0.8764 \\
(-3.65)\end{array}$ & $\begin{array}{c}\mathbf{0 . 3 8 2 2} \\
(\mathbf{1 . 9 3 )}\end{array}$ & $\begin{array}{l}0.5216 \\
(3.10)\end{array}$ \\
\hline & Male & $\begin{array}{c}0.32 \\
(-0.06,0.84)\end{array}$ & $\begin{array}{c}10.42236 \\
(27.63)\end{array}$ & $\begin{array}{c}-0.7552 \\
(-2.90)\end{array}$ & $\begin{array}{c}-0.0726 \\
(-0.31)\end{array}$ & $\begin{array}{c}\mathbf{0 . 7 8 5 5} \\
(\mathbf{3 . 8 5})\end{array}$ \\
\hline \multirow[t]{3}{*}{ Urban } & Female & $\begin{array}{c}0.03 \\
(-0.44,0.68)\end{array}$ & $\begin{array}{c}18.5646 \\
(98.91)\end{array}$ & $\begin{array}{l}1.9460 \\
(10.75)\end{array}$ & $\begin{array}{l}1.7016 \\
(9.52)\end{array}$ & $\begin{array}{l}1.2600 \\
(7.12)\end{array}$ \\
\hline & Total & $\begin{array}{c}0.31 \\
(-0.16,0.80)\end{array}$ & $\begin{array}{c}12.1303 \\
(32.97)\end{array}$ & $\begin{array}{c}-0.4103 \\
(-1.60)\end{array}$ & $\begin{array}{c}\mathbf{0 . 3 3 7 5} \\
(\mathbf{1 . 7 0 )}\end{array}$ & $\begin{array}{c}0.8321 \\
(4.10)\end{array}$ \\
\hline & Male & $\begin{array}{c}0.62 \\
(0.20,1.09)\end{array}$ & $\begin{array}{c}17.0756 \\
(11.22)\end{array}$ & $\begin{array}{c}-1.2869 \\
(-1.48)\end{array}$ & $\begin{array}{c}0.1368 \\
(0.21)\end{array}$ & $\begin{array}{l}1.2063 \\
(2.38)\end{array}$ \\
\hline \multirow[t]{2}{*}{ Youth } & Female & $\begin{array}{c}0.05 \\
(-0.38,0.65)\end{array}$ & $\begin{array}{c}17.0707 \\
(84.09)\end{array}$ & $\begin{array}{c}-3.211 \\
(-16.22)\end{array}$ & $\begin{array}{c}1.1664 \\
(6.24)\end{array}$ & $\begin{array}{c}1.0700 \\
(5.82)\end{array}$ \\
\hline & Total & $\begin{array}{c}0.48 \\
(0.07,1.03)\end{array}$ & $\begin{array}{c}17.3811 \\
(20.89)\end{array}$ & $\begin{array}{c}-1.9056 \\
(-3.78)\end{array}$ & $\begin{array}{c}0.5286 \\
(1.29)\end{array}$ & $\begin{array}{c}1.1823 \\
(3.45)\end{array}$ \\
\hline
\end{tabular}


Figure 1: Turkish unemployment rates

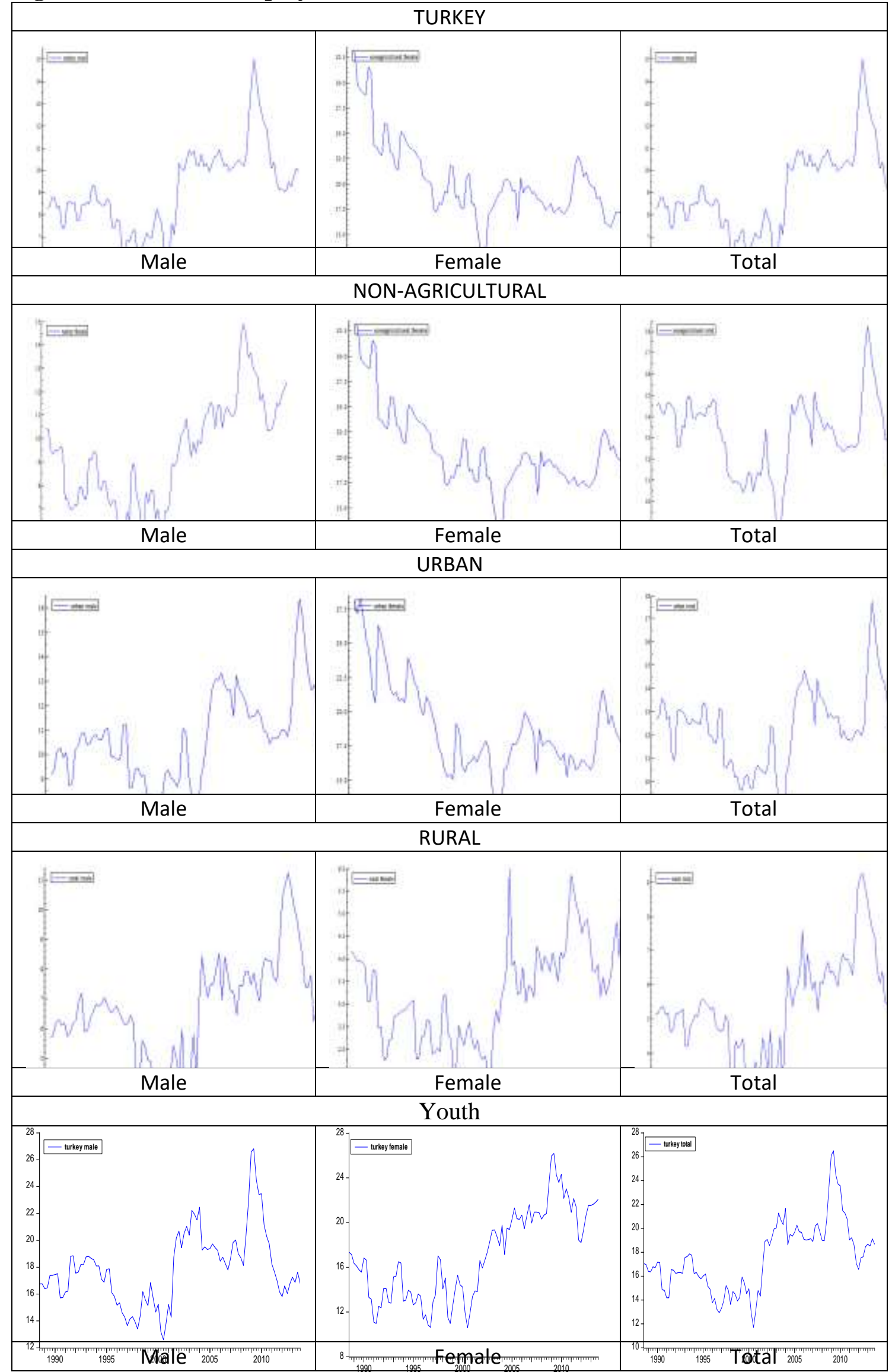


Appendix: ADF unit root tests

\begin{tabular}{|c|c|c|c|}
\hline \multicolumn{4}{|c|}{ Rural } \\
\hline & No regressors & With Intercept & Intercept and Trend \\
\hline Male & -0.1763 & -2.3838 & -2.7038 \\
\hline Female & -0.1628 & -2.5042 & $-3.5614 * * *$ \\
\hline Total & -0.1080 & -2.2265 & -2.8718 \\
\hline \multicolumn{4}{|c|}{ Urban } \\
\hline & No regressors & With Intercept & Intercept and Trend \\
\hline Male & -0.3383 & $-2.997 * * *$ & -3.0642 \\
\hline Female & -1.3488 & $-3.0779 * * *$ & -3.1445 \\
\hline Total & -0.4291 & $-3.0825 * * *$ & -3.1366 \\
\hline \multicolumn{4}{|c|}{ Non-agricultural } \\
\hline & No regressors & With Intercept & Intercept and Trend \\
\hline Male & -0.5055 & $-3.2062 * * *$ & -3.1767 \\
\hline Female & -1.7487 & $-2.9564 * * *$ & -2.716 \\
\hline Total & -0.6442 & $-3.2956^{* * *}$ & -3.2779 \\
\hline \multicolumn{4}{|c|}{ Turkey } \\
\hline & No regressors & With Intercept & Intercept and Trend \\
\hline Male & -0.3088 & -2.2977 & -2.4694 \\
\hline Female & 0.2131 & -0.9911 & -2.6592 \\
\hline Total & -0.1821 & -2.118 & -2.7333 \\
\hline
\end{tabular}

